\title{
KLASIFIKASI KAIN SONGKET LOMBOK BERDASARKAN FITUR GLCM DAN MOMENT INVARIANT DENGAN TEKNIK PENGKLASIFIKASIAN LINEAR DISCRIMINANT ANALYSIS (LDA)
}

\author{
(Classification of Lombok Songket Using GLCM and Invariant Moment Features and \\ Linear Discriminant Analysis (LDA) Classifier)
}

\author{
Nurhalimah*, I Gede Pasek Suta Wijaya, Fitri Bimantoro \\ Program Studi Teknik Informatika, Fakultas Teknik, Universitas Mataram \\ Jl. Majapahit 62, Mataram, Lombok NTB, INDONESIA \\ Email: nurha.h5h@gmail.com, [gpsutawijaya, bimo]@unram.ac.id
}

\begin{abstract}
Songket is one of Indonesia's cultural heritage that is still maintained today. One area that is famous for its songket weaving in Lombok. Lombok Songket has diverse, unique, and beautiful motifs. Public knowledge of Lombok songket motifs is still minimal and the difference between one motif with another is still unknown. Information about the characteristics of the Lombok songket type has not been well documented. Therefore, we need a system that can classify Lombok songket automatically. In this study, a system was developed that could classify Lombok songket based on texture features and shape features using Linear Discriminant Analysis (LDA). The GLCM method is used in the texture feature extraction process and the Moment Invariant method is used in the feature extraction process. The total data used in this study is 1000 images from 10 Lombok songket motifs which are divided into training data and test data. The highest accuracy is $98.33 \%$. Obtained on the GLCM feature with 300x300 pixel image resolution using the most effective features: IDM, Entropy, and Energy.
\end{abstract}

Keywords: GLCM, Image Classification, Linear Discriminant Analysis (LDA), Lombok Songket, Moment Invariant.

*Penulis Korespondensi

\section{Pendahuluan}

Songket adalah salah satu warisan budaya Indonesia yang masih terjaga hingga kini. Songket adalah jenis kain tenunan tradisional Melayu dan Minangkabau di Indonesia, Malaysia, dan Brunei. Songket digolongkan dalam keluarga tenunan brokat. Songket ditenun dengan tangan dengan benang emas dan perak dan pada umumnya dikenakan pada acaraacara resmi [1]. Daerah yang terkenal dengan kain tenun songket salah satunya adalah Lombok. Songket Lombok memiliki motif yang beragam, unik, dan indah. Motif ini dipengaruhi oleh kebudayaan yang ada pada masyarakat Lombok.

Pengetahuan masyarakat akan motif-motif songket Lombok masih minim dan perbedaan antara motif yang satu dengan motif yang lain masih belum diketahui. Kurangnya pendataan secara komputerisasi menjadi penyebab hal tersebut dan belum adanya aplikasi yang dapat menganalisis songket Lombok yang dapat membantu masyarakat untuk mendapatkan informasi.
Motif songket dapat diklasifikasikan menjadi beberapa kelas berdasarkan fitur tekstur menggunakan berbagai macam metode. Metode untuk ekstraksi fitur tekstur salah satunya adalah Gray Level Co-Occurance Matrix (GLCM). GLCM adalah metode ekstraksi ciri yang menggunakan perhitungan tekstur pada orde kedua yaitu memperhitungkan pasangan dua piksel citra asli. Hasil pada penelitian sebelumnya [2] menunjukkan bahwa GLCM sebagai metode ekstraksi ciri tekstur memberikan hasil yang sangat baik.

Selain tekstur, fitur yang dapat diekstrak dari songket adalah fitur bentuk. Metode untuk ekstraksi fitur bentuk salah satunya adalah Moment Invariant. Metode Moment Invariant adalah metode ekstraksi ciri bentuk yang nilainya tidak berubah terhadap perlakuan rotasi, translasi, pencerminan dan penskalaan. Pada penelitian sebelumnya [3], penggunaan Moment Invariant pada klasifikasi motif batik telah memberikan hasil yang sangat baik.

Pada pengenalan pola ada beberapa metode untuk klasifikasi salah satunya adalah Linear Discriminant Analysis (LDA). LDA bertujuan untuk 
mengklasifikasikan objek ke salah satu dari dua atau lebih kelompok berdasarkan berbagai fitur yang menggambarkan kelas atau kelompok. LDA juga memiliki fungsi untuk memaksimalkan diskriminasi antar kelas dan meminimalkan persebaran dalam kelas [4]. Oleh karena itu, metode LDA dapat digunakan dalam sistem klasifikasi songket Lombok.

Berdasarkan uraian tersebut, maka pada penelitian ini akan dibangun sistem klasifikasi songket Lombok menggunakan metode Gray Level CoOccurrence Matrix (GLCM) untuk ekstraksi fitur tekstur dan metode Moment Invariant untuk ekstraksi fitur bentuk. Hasil ekstraksi tersebut akan diklasifikasikan menggunakan metode Linear Discriminant Analysis (LDA). Perbedaan dari penelitian sebelumnya [5] yaitu data yang digunakan lebih banyak yaitu sebanyak 1000 citra dari 10 motif songket Lombok dengan sudut pengambilan citra sebesar 90 dengan jarak $70 \mathrm{~cm}$. Tujuan penelitian ini adalah untuk mengetahui fiturfitur GLCM dan Moment Invariant yang paling efektif dalam sistem klasifikasi songket Lombok.

\section{TinjauAn PUSTAKa}

Pada penelitian terdahulu yang terkait dengan penelitian ini adalah penelitian tentang pengenalan motif songket Melayu yang dibangun menggunakan ekstraksi fitur Principal Component Analysis (PCA) dan Gray Level Co-Occurrence Matrix (GLCM) memiliki hasil akurasi $97 \%$ untuk GLCM dan $82 \%$ untuk PCA [5]. Penelitian serupa telah dilakukan membahas tentang pengenalan dan klasifikasi citra tekstil tradisional dengan menggunakan deteksi tepi canny, local color histogram dan Co-Occurrence Matrix. Hasil penelitian menunjukan bahwa nilai rata-rata hasil yang dikenal sesuai dengan kelompok tekstil adalah $88.03 \%$. Nilai tertinggi menggunakan ekstraksi ciri tekstur sebesar 99.37\% [2]. Penelitian ini menunjukkan bahwa GLCM sangat baik digunakan dalam ekstraksi fitur tekstur. Penelitian selanjutnya adalah penelitian tentang pengenalan jenis batik tulis dan batik cap menggunakan GLCM sebagai ekstraksi fitur. Hasil akurasi dari penelitian ini adalah sebesar 90\%[6]. Penelitian lain yang telah dilakukan yaitu tentang klasifikasi motif kain batik menggunakan GLCM untuk ekstraksi fitur tekstur. Hasil akurasi yang diperoleh pada sudut 0 o sebesar $74.2 \%$, sudut 45 - sebesar $64.5 \%$, sudut 90 o sebesar $66.65 \%$ dan 135 o sebesar $67.5 \%$. Penggabungan seluruh nilai fitur menghasilkan akurasi pada tahap pelatihan sebesar $80.65 \%$ dan pada tahap pengujian sebesar $77.14 \%[7]$.

Penelitian lain tentang penggunaan Moment Invariant untuk klasifikasi motif batik telah berhasil dilakukan dengan nilai akurasi tertinggi yang didapat mencapai $100 \%$. Citra uji yang digunakan sebanyak 40 citra dari motif batik yang digunakan dengan ukuran citra 256×256 piksel yang dikenai preprocessing biner, opening dan closing terlebih dahulu[3]. Penelitian selanjutnya tentang penggunaan Moment Invariant dalam pengenalan pola tulisan tangan suku kata aksara sasak yang menggunakan data input sejumlah 2700 data telah berhasil dilakukan dengan akurasi $89,76 \%$ pada pengujian pertama dan $92,52 \%$ pada pengujian kedua[8].

Penelitian berikutnya menggunakan metode LDA yang digunakan dalam proses klasifikasi citra. Terdapat penelitian terdahulu tentang klasifikasi jenis pohon mangga. Hasil penelitian menunjukan keberhasilan menggunakan metode klasifikasi LDA dengan akurasi sebesar 90\% [9]. Penelitian lain yang mendukung proses pengklasifikasian menggunakan metode LDA yaitu penelitian pengklasifikasian ras manusia melalui citra wajah menggunakan metode LDA memberikan akurasi sebesar $82 \%$ dengan menggunakan 90 sampel citra latih dan 90 citra uji [10]. Penelitian selanjutnya yang menggunakan metode LDA untuk klasifikasi yaitu tentang pendeteksi jenis autis pada anak usia dini menghasilkan akurasi sebesar 88\%[11]. Selanjutnya penelitian mengenai pengenalan wajah dengan metode LDA juga telah berhasil dilakukan, dimana tingkat akurasi yang diperoleh sampai 98,33\% dari 66 citra wajah dari 22 orang[12]. Hasil akurasi pada penelitian tersebut menunjukkan bahwa metode klasifikasi LDA memberikan hasil yang sangat baik sebagai metode klasifikasi.

Dari pemaparan tersebut, maka dalam penelitian ini akan dibangun sistem klasifikasi songket Lombok. Metode yang digunakan adalah Gray Level CoOccurrence Matrix (GLCM) untuk ekstraksi fitur tekstur. Dari penelitian sebelumnya metode GLCM memiliki tingkat keberhasilan tertinggi sebesar $99.37 \%$. Untuk ekstraksi fitur bentuk digunakan metode Moment Invariant yang mana pada penelitian sebelumnya Moment Invariant memiliki tingkat keberhasilan lebih dari $80 \%$. Sedangkan untuk klasifikasi digunakan metode Linear Discriminant Analysis (LDA) yang mampu memperoleh tingkat akurasi tertinggi hingga $98,33 \%$.

\section{Metode Penelitian}

\subsection{Alat dan Bahan}

Alat dan bahan yang digunakan dalam penelitian ini adalah sebagai berikut:

a. Laptop (Intel Celeron N4000 dengan RAM 4GB).

b. Sistem operasi Windows 10 Pro 64-bit. 
c. Kamera DSLR Canon.

d. Anaconda3 2019.03 (Python 3.7.3 64-bit).

e. Citra songket Lombok sebanyak 1000 citra dari 10 motif yaitu Anggrek, Cangkir, Kabut, Keker, Keker Ngangak, Klukus Ulah, Kupu-kupu, Lepang, Nanas, Subahnale Rante dengan format JPEG dengan ukuran maksimal 300×300 piksel. Jumlah citra setiap motif yaitu 100 citra. Akuisisi citra menggunakan kamera digital dengan jarak $70 \mathrm{~cm}$ dengan sudut 90․ Hasil dari akuisisi citra adalah citra berukuran 5184x3456 piksel. Setelah itu, citra hasil akuisisi akan dikenai proses cropping dan di-resize menjadi 64×64 piksel, 128×128 piksel, 256×256 piksel dan $300 \times 300$ piksel. Pembagian data latih dan data uji adalah $70 \%$ untuk data latih dan $30 \%$ untuk data uji.

\subsection{Proses Penelitian}

Secara sederhana proses penelitian yang terdiri atas 6 tahap seperti disajikan pada pada Gambar 1 .

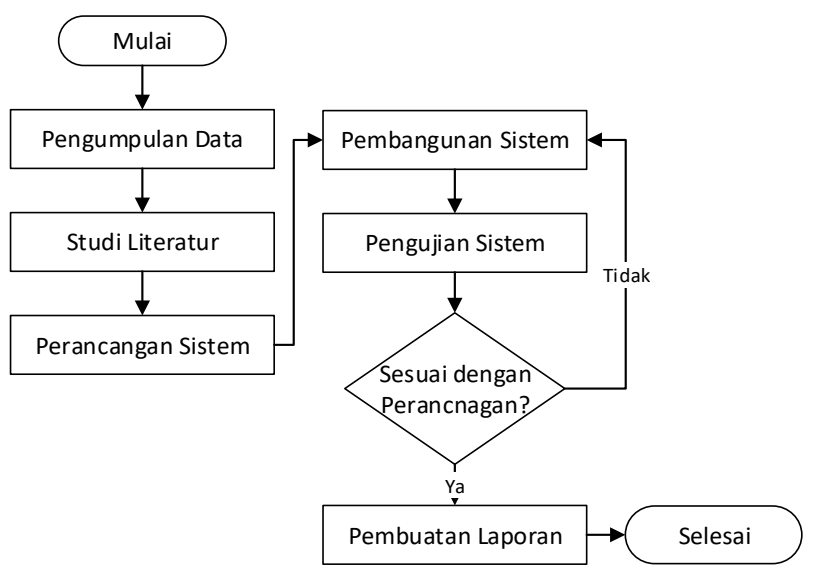

Gambar 1. Diagram alir proses penelitian

1. Pengumpulan Data

Tahap pertama dari rancangan penelitian ini adalah pengumpulan data. Pengumpulan data dilakukan dengan datang langsung ke art shop songket yang berada di desa Sukarare. Informasi mengenai motif-motif songket Lombok diperoleh dari hasil wawancara dengan pemilik art shop. Data yang dikumpulkan terdiri atas 10 motif songket Lombok yaitu Anggrek, Cangkir, Kabut, Keker, Keker Ngangak, Klukus Ulah, Kupu-kupu, Lepang, Nanas, Subahnale Rante. Untuk pengambilan citra songket, kamera yang digunakan adalah kamera DSLR Canon EOS 600D. Jarak pengambilan citra adalah $70 \mathrm{~cm}$. Proses ini, menghasilkan 100 citra songket Lombok untuk masingmasing motif, sehingga total citra songket yaitu 1000 citra. Citra songket Lombok ini kemudian dibagi menjadi citra latih dan citra uji dengan pembagian 700 citra latih dan 300 citra uji dengan persentase $70 \%$ berbanding $30 \%$. Adapun contoh sample citra songket Lombok yang telah dikumpulkan dapat dilihat pada Tabel I.

\begin{tabular}{|c|c|c|c|c|c|}
\hline Citra & & 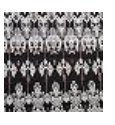 & 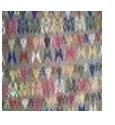 & 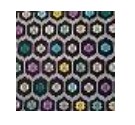 & 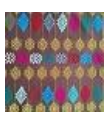 \\
\hline Motif & Lepang & $\begin{array}{c}\text { Keker } \\
\text { Ngangak }\end{array}$ & $\begin{array}{l}\text { Kupu- } \\
\text { kupu }\end{array}$ & $\begin{array}{c}\text { Subahnale } \\
\text { Rante }\end{array}$ & Kabut \\
\hline Citra & 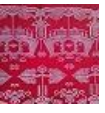 & & 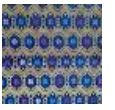 & & \\
\hline Motif & Keker & Nanas & $\begin{array}{c}\text { Klukus } \\
\text { Ulah }\end{array}$ & Cangkir & Anggrek \\
\hline
\end{tabular}

2. Studi Literatur

Tahap kedua adalah melakukan studi literatur untuk mempelajari cara pembangunan dan prinsip kerja dari metode yang digunakan yaitu metode LDA untuk klasifikasi. GLCM dan Moment Invariant untuk ekstraksi fitur citra.

3. Perancangan Sistem

Tahap ketiga adalah melakukan perancangan sistem. Pada tahap ini, sistem dirancang agar dapat melakukan klasifikasi songket dengan metode yang digunakan yaitu GLCM dan Moment Invariant untuk ekstraksi fitur citra dan metode LDA digunakan sebagai metode klasifikasi.

4. Pembangunan sistem

Tahap keempat adalah memulai pembangunan sistem dengan metode yang digunakan. Pada penelitian ini, metode yang digunakan adalah GLCM dan Moment Invariant untuk ekstraksi fitur citra dan metode LDA digunakan sebagai metode klasifikasi.

5. Pengujian sistem

Setelah pembangunan sistem selesai, tahap kelima adalah melakukan pengujian sistem. Sistem dikatakan berhasil jika sudah sesuai dengan perancangan dan dapat mengenali motif songket Lombok dengan tepat. Jika sistem yang telah dibangun berhasil maka akan dilanjutkan ke tahap enam. Namun, jika sistem belum berhasil maka langkah selanjutnya kembali ke pembangunan sistem.

6. Pembuatan laporan

Langkah terakhir yang dilakukan setelah pengujian sistem memberikan hasil yang tepat adalah pembuatan laporan. Pembuatan laporan dari awal pengumpulan data sampai akhir pembuatan sistem. 


\subsection{Sistem Klasifikasi Songket}

Berikut alur proses klasifikasi songket dalam bentuk blok diagram sistem yang disajikan pada Gambar 2.

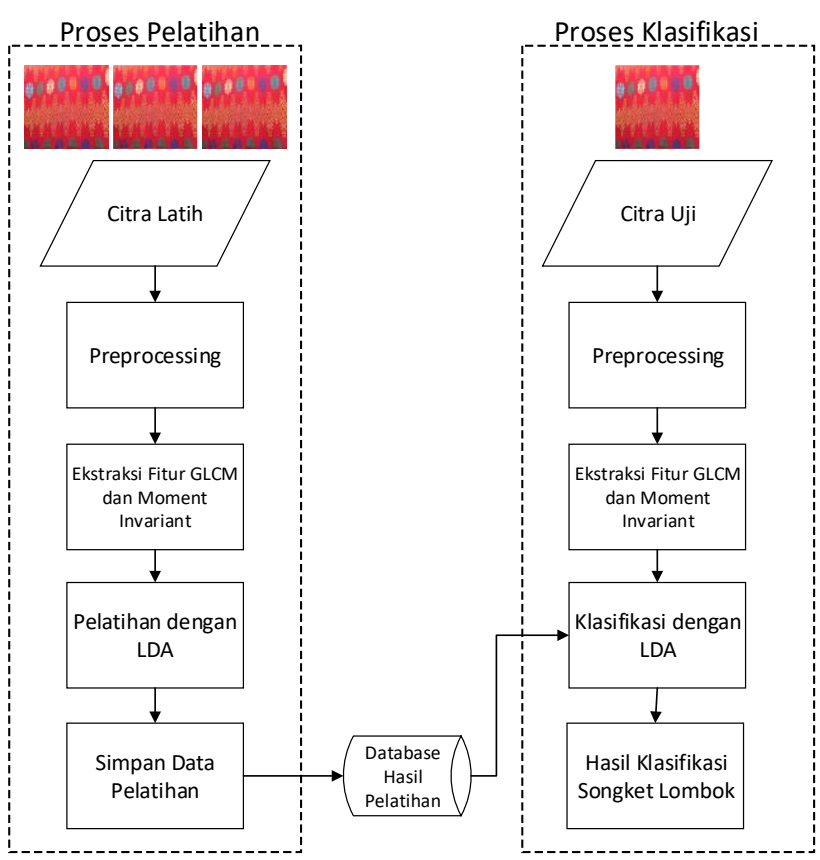

Gambar 2. Blok diagram sistem klasifikasi Songket

Gambar 2 menggambarkan proses klasifikasi songket berdasarkan fitur GLCM dan Moment Invariant dengan pengklasifikasian LDA. Terdapat 2 tahapan utama pada proses klasifikasi songket ini yaitu pelatihan dan klasifikasi.

\subsubsection{Proses Pelatihan}

Tahap-tahap proses pelatihan dapat dijelaskan sebagai berikut:

1. Input citra songket Lombok untuk pelatihan. Citra yang dimasukkan ke dalam sistem merupakan citra yang telah di-crop dan di-resize menjadi 4 ukuran berbeda yaitu $64 \times 64$ piksel, $128 \times 128$ piksel, 256x256 piksel dan 300x300 piksel. Proses resizing dilakukan agar waktu komputasi yang dibutuhkan sistem tidak besar. Selain itu, 4 ukuran berbeda dari citra tersebut akan menjadi salah satu parameter pada skenario pengujian sistem. Proses cropping dan resize dilakukan di luar sistem untuk menghemat waktu komputasi di dalam sistem. Total citra yang digunakan pada proses pelatihan adalah 700 citra.

2. Tahap preprocessing merupakan tahap awal pengolahan citra asli sebelum citra tersebut diekstraksi pada proses pelatihan maupun proses klasifikasi. Karena proses cropping dan resizing dilakukan diluar sistem, maka pada preprocessing yang dilakukan di dalam sistem adalah proses grayscalling.

3. Ekstraksi fitur yang dilakukan pada penelitian ini dibagi menjadi dua, yaitu ekstraksi fitur tekstur dan fitur bentuk. Ekstraksi fitur tekstur dilakukan menggunakan metode GLCM sedangkan ekstraksi fitur bentuk dilakukan menggunakan metode Moment Invariant.

4. Pelatihan dengan LDA dilakukan untuk mendapatkan nilai dari training sample yang dapat digunakan untuk mengklasifikasikan citra songket Lombok.

5. Database hasil pelatihan berisi nilai dari training sample yang dihasilkan dari tahap pelatihan dengan LDA.

\subsubsection{Proses Klasifikasi}

Tahap-tahap proses klasifikasi dapat dijelaskan sebagai berikut:

1. Input citra songket Lombok untuk pelatihan. Citra yang dimasukkan ke dalam sistem merupakan citra yang telah di-crop dan di-resize menjadi 4 ukuran berbeda yaitu $64 \times 64$ piksel, $128 \times 128$ piksel, 256×256 piksel dan 300×300 piksel. Proses resizing dilakukan agar waktu komputasi yang dibutuhkan sistem tidak besar. Selain itu, 4 ukuran berbeda dari citra tersebut akan menjadi salah satu parameter pada skenario pengujian sistem. Proses cropping dan resize dilakukan di luar sistem untuk menghemat waktu komputasi di dalam sistem. Total citra yang digunakan pada proses klasifikasi adalah 300 citra.

2. Tahap preprocessing yang dilakukan di dalam sistem pada proses klasifikasi sama dengan preprocessing pada proses pelatihan yaitu proses grayscalling.

3. Ekstraksi fitur yang dilakukan pada penelitian ini dibagi menjadi dua, yaitu ekstraksi fitur tekstur dan fitur bentuk. Ekstraksi fitur tekstur dilakukan menggunakan metode GLCM sedangkan ekstraksi fitur bentuk dilakukan menggunakan metode Moment Invariant.

4. Tahap klasifikasi dilakukan dengan metode LDA untuk membedakan motif citra songket Lombok. Data hasil pelatihan dimuat untuk dibandingkan dengan data uji.

5. Keluaran akhir dari proses klasifikasi berupa jenis motif songket Lombok.

\subsection{Preprocessing}

Pada penelitian ini, preprocessing yang dilakukan terdiri dari proses cropping, resizing, dan konversi warna citra. Cropping dilakukan untuk mengambil citra 
yang dibutuhkan dan membuang bagian yang tidak dibutuhkan. Resizing dilakukan untuk mengubah resolusi citra menjadi $64 \times 64$ piksel, $128 \times 128$ piksel, $256 \times 256$ piksel dan 300×300 piksel. Proses cropping dan resizing dilakukan diluar sistem.

Setelah resolusi citra diubah, selanjutnya ruang warna citra dikonversi dari RGB menjadi ruang warna grayscale. Proses ini merupakan proses pertama yang dilakukan di dalam sistem setelah input citra. Gambar 3 merupakan contoh hasil konversi dari ruang warna RGB menjadi grayscale.
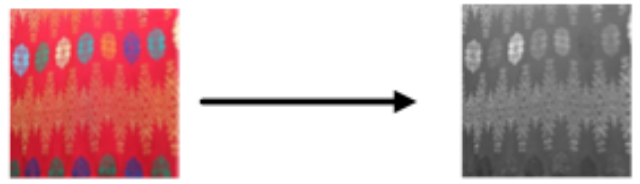

Gambar 3. Hasil konversi dari RGB ke grayscale

Proses cropping, resizing, dan konversi ruang warna yang dilakukan pada citra dilakukan untuk mempermudah proses ekstraksi fitur yang akan dilakukan pada citra. Tahap preprocessing ini dilakukan terhadap 10 motif citra songket Lombok yang ada.

\subsection{Gray Level Co-Occurrence Matrix (GLCM)}

GLCM pertama kali diperkenalkan dengan nama Gray-Tone Spatial-Dependence Matrix. GLCM adalah matriks yang menggambarkan frekuensi munculnya pasangan dua piksel dengan intensitas tertentu dalam jarak $\mathrm{d}$ dan orientasi arah dengan sudut $\theta$ tertentu dalam citra. Jarak dinyatakan dalam piksel, biasanya 1 , 2, 3 dan seterusnya. Orientasi sudut dinyatakan dalam derajat, yaitu $0^{\circ}, 45^{\circ}, 90^{\circ}$ dan $135^{\circ}$. Adapun arah sudut dalam matriks GLCM dapat dilihat pada Gambar 4 [13].

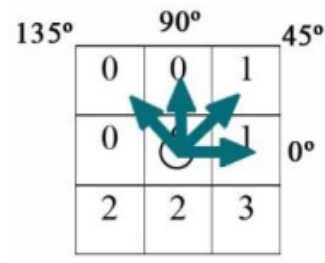

Gambar 4. Arah dalam GLCM

GLCM adalah metode ekstraksi fitur tekstur statistik orde kedua. Dimana pasangan piksel dengan nilai-nilai spesifik dan dalam hubungan spasial yang ditentukan terjadi dalam suatu gambar dimasukkan ke dalam matriks dan fitur statistik diekstraksi dari matriks ini. Perhitungan memberikan fungsi yang menjadi ciri tekstur suatu gambar. Jumlah baris dan kolom dalam matriks sama dengan jumlah tingkat abuabu, $G$, dalam gambar. Elemen matriks $P(i, j)$ adalah entri dalam matriks dependensi spasial gray-tone yang dinormalisasi. 5 fitur GLCM yang paling relevan untuk digunakan adalah Contrast, Inverse Difference Moment, Entropy, Correlation, Energy [6][14][15][16].

$$
\begin{gathered}
\text { Contrast }=\sum_{n=0}^{G-1} n^{2}\left\{\sum_{i=1}^{G} \sum_{j=1}^{G} P(i, j)\right\} \\
I D M=\sum_{i=1}^{G-1} \sum_{j=1}^{G-1} \frac{1}{1+(i-j)^{2}} P(i, j)
\end{gathered}
$$

$$
\begin{gathered}
\text { Entropy }=-\sum_{i=1}^{G-1} \sum_{j=1}^{G-1} P(i, j) \times \log (P(i, j)) \\
\text { Energy }=\sum_{i=0}^{G-1} \sum_{j=0}^{G-1} P(i, j)^{2} \\
\text { Correlation }=\sum_{i, j=0}^{N-1} P(i, j) \frac{(i-\mu)(j-\mu)}{\sigma^{2}}
\end{gathered}
$$

Dimana

$$
\begin{gathered}
\mu=\sum_{i, j=0}^{N-1} i P(i, j) \\
\sigma=\sum_{i, j=0}^{N-1} P(i, j)(i-\mu)^{2}
\end{gathered}
$$

\subsection{Moment Invariant}

Moment Invariant merupakan fungsi non-linear yang invariant terhadap rotasi, translasi dan skala dalam moment geometri citra. Jika ada sebuah citra dengan nilai intensitas adalah $f(x, y)$ nilai $x$ sebagai baris dan y sebagai kolom maka Moment Invariant yang mentransformasikan fungsi citra $f(x, y)$ pada sistem diskrit. Mekanismenya dilakukan dengan menghitung moment citra dan moment pusat citra menggunakan Persamaan (8)[8].

$$
m_{p q}=\sum_{x=0}^{W-1} x \sum_{y=0}^{H-1} y x^{p} y^{q} f(x, y)
$$

Dimana $\mathrm{m}$ adalah moment citra, $\mathrm{p}, \mathrm{q}$ adalah orde moment, $f$ adalah nilai intensitas warna citra, $x, y$ adalah koordinat piksel dan $\mathrm{H}, \mathrm{W}$ adalah tinggi dan lebar citra.

Moment citra yang invariant terhadap translasi citra adalah dengan orde $m_{00}, m_{01}, m_{02}, m_{03}, m_{10}, m_{11}$, $m_{12}, m_{20}, m_{21}, m_{31}$. Selanjutnya, ditentukan koordinat pusat citra berdasarkan moment citra yang dihitung dengan menggunakan Persamaan (9) dan Persamaan (10).

$$
\begin{aligned}
& \bar{x}=\frac{m_{10}}{m_{00}} \\
& \bar{y}=\frac{m_{01}}{m_{00}}
\end{aligned}
$$

m00 adalah jumlah total piksel yang membentuk objek, sedangkan $m 10$ dan $m 11$ adalah pusat massa objek. Selanjutnya untuk memperoleh moment 
invariant terhadap rotasi maka moment pusat diperoleh dengan menggunakan Persamaan (11).

$$
\mu_{p q}=\sum_{x} x \sum_{y} y(x-\bar{x})^{p}(y-\bar{y})^{q}
$$

Dimana $\mu$ adalah moment pusat dan $\bar{x}, \bar{y}$ adalah pusat citra

Moment pusat yang terbentuk sensitif terhadap transformasi rotasi dan penskalaan. Maka dari itu dilakukan normalisasi terhadap moment pusat $\left(\mu_{\mathrm{pq}}\right)$ melalui Persamaan (12) dan Persamaan (13).

$$
\begin{gathered}
\eta_{p q}=\frac{\mu_{p q}}{\mu_{00}^{\gamma}} \\
\gamma=\left(\frac{p+q}{2}\right)+1
\end{gathered}
$$

Berdasarkan normalisasi moment pusat dapat dihitung tujuh vector moment invariant dangan Persamaan (14) sampai dengan Persamaan (20).

$$
\begin{gathered}
\varphi 1=\eta_{20}+\eta_{02} \\
\varphi 2=\left(\eta_{20}-\eta_{02}\right)^{2}+4 \eta_{11}^{2} \\
\varphi 3=\left(\eta_{30}-3 \eta_{12}\right)^{2}+\left(3 \eta_{21}-\eta_{03}\right)^{2} \\
\varphi 4=\left(\eta_{30}+\eta_{12}\right)^{2}+\left(\eta_{21}+\eta_{03}\right)^{2}
\end{gathered}
$$

$$
\varphi 5=\left(\eta_{30}-3 \eta_{12}\right)\left(\eta_{30}+\eta_{12}\right)\left[\left(\eta_{30}+\eta_{12}\right)^{2}-\right.
$$$$
\left.3\left(\eta_{21}+\eta_{03}\right)^{2}\right]+\left(3 \eta_{21}-\eta_{03}\right)\left(\eta_{21}+\eta_{03}\right)^{2}\left[3 \left(\eta_{30}+\right.\right.
$$$$
\left.\left.\eta_{12}\right)^{2}-\left(\eta_{21}+\eta_{03}\right)^{2}\right]
$$

$$
\varphi 6=\left(\eta_{20}-\eta_{02}\right)\left[\left(\eta_{30}+\eta_{12}\right)^{2}-\left(\eta_{21}+\eta_{03}\right)^{2}\right]+
$$$$
4 \eta_{11}\left(\eta_{30}+\eta_{12}\right)\left(\eta_{21}+\eta_{03}\right)
$$

$$
\begin{aligned}
& \varphi 7=\left(3 \eta_{21}-\eta_{03}\right)\left(\eta_{30}+\eta_{12}\right)\left[\left(\eta_{30}+\eta_{12}\right)^{2}-\right. \\
& \left.3\left(\eta_{21}+\quad \eta_{03}\right)^{2}\right]+\left(3 \eta_{12}-\right. \\
& \left.\eta_{30}\right)\left(\eta_{21}+\eta_{03}\right)\left[3\left(\eta_{30}+\eta_{12}\right)^{2}-\left(\eta_{21}-\eta_{03}\right)^{2}\right]
\end{aligned}
$$

\subsection{Linear Discriminant Analysis (LDA)}

Sistem klasifikasi songket Lombok ini menggunakan metode LDA. Tujuan LDA adalah untuk mengklasifikasikan objek ke salah satu dari dua atau lebih kelompok berdasarkan berbagai fitur yang menggambarkan kelas atau kelompok. Proses kalsifikasi songket Lombok terdiri dari proses pelatihan dan proses klasifikasi. Untuk melakukan proses pelatihan terlebih dahulu dicari matriks kovarian dalam kelas SW, dan matriks kovarian antar kelas SB yang didefinisikan masing-masing sebagai berikut [4]:

$$
S_{W}=\sum_{i=1}^{c} \sum_{x_{k} \in X_{i}}\left(x_{k}-\mu_{i}\right)\left(x_{k}-\mu_{i}\right)^{T}
$$

$$
S_{B}=\sum_{i=1}^{c} N_{i}\left(\mu_{i}-\mu\right)^{T}\left(\mu_{i}-\mu\right)
$$

Dimana $\mathrm{X}_{\mathrm{k}}$ adalah image ke- $\mathrm{k}, \mathrm{N}_{\mathrm{i}}$ adalah jumlah sampel pada kelas $X_{i}, c$ adalah jumlah kelas, $\mu$ adalah image rata-rata dari kelas dan $\mu_{\mathrm{i}}$ adalah image ratarata pada kelas-i. Selanjutnya dilakukan pencarian eigen vector dari matriks hasil perkalian antara SB dengan invers SW menggunakan Persamaan (23).

$$
\operatorname{cov}=S_{B} S_{w}^{-1}
$$

Eigen vector dipilih berdasarkan nilai eigen value terbesar. Nilai eigen vector tersebut digunakan untuk melakukan proyeksi untuk setiap data latih menggunakan Persamaan (24)

$$
F P_{T}=x_{i} w
$$

Dimana $\mathrm{FP}_{\mathrm{T}}$ adalah nilai proyeksi data, $\mathrm{x}_{\mathrm{i}}$ adalah data masukan dan $\mathrm{w}$ adalah nilai eigen vector yang dipilih berdasarkan nilai eigen value terbesar. Hasil dari proses pelatihan berupa proyeksi dari setiap data latih kemudian disimpan untuk dibandingkan dengan data uji.

Proses klasifikasi dilakukan dengan cara melakukan proyeksi terhadap data uji. Proyeksi data uji dilakukan dengan mengalikan data uji dengan eigen vector yang digunakan pada proses pelatihan. Tahap klasifikasi dilakukan dengan cara membandingkan data proyeksi hasil pelatihan dengan hasil proyeksi dari data uji. Selanjutnya untuk mengetahui kelas dari data uji dilakukan pencarian jarak antara proyeksi data latih dengan proyeksi data uji menggunakan Persamaan (25)

$$
d_{i j}=\frac{\sum_{k=1}^{n} x_{i k} \cdot x_{j k}}{\sqrt{\sum_{k=1}^{n} x_{i k}^{2} \sum_{k=1}^{n} x_{j k}^{2}}}
$$

Dimana $\mathrm{d}_{\mathrm{ij}}$ adalah jarak antara proyeksi data latih dan data $u j i, x_{i k}$ adalah proyeksi data latih dan $x_{i j}$ adalah proyeksi data uji. Hasil dari pencarian jarak antara proyeksi data latih dan data uji kemudian diurutkan berdasarkan dari yang paling besar hingga yang paling kecil. Hasil pencarian jarak yang paling besar adalah hasil klasifikasi dari data uji. Hasil ini kemudian diverifikasi dengan cara membandingkan kelas sesungguhnya dengan kelas hasil klasifikasi.

\subsection{Evaluasi Hasil Klasifikasi}

Pada penelitian ini, dilakukan evaluasi terhadap hasil klasifikasi dengan menghitung nilai True Positive, True Negative, False Positive dan False Negative. True Positive adalah banyaknya hasil klasifikasi benar untuk suatu kelas yang bernilai positive. True Negative adalah banyaknya hasil klasifikasi benar untuk suatu kelas yang bernilai negative. False Positive adalah banyaknya 
hasil klasifikasi salah untuk suatu kelas yang bernilai positive. False Negative adalah banyaknya hasil klasifikasi salah untuk suatu kelas yang bernilai negative. Keempat nilai tersebut dapat dihitung dengan confusion matrix pada Tabel II [13]. Nilai-nilai inilah yang kemudian digunakan untuk menghitung parameter-parameter evaluasi hasil klasifikasi.

TABEL II. CONFUSION MATRIX

\begin{tabular}{|l|c|c|}
\hline $\begin{array}{l}\text { Kelas } \\
\text { Sebenarnya Klasifikasi }\end{array}$ & Positif & Negatif \\
\hline Positif & TP & FN \\
\hline Negatif & FP & TN \\
\hline
\end{tabular}

Akurasi dapat diartikan sebagai proporsi dari dua kelas (positif dan negatif) dari jumlah total kelas yang diujikan. Berikut ini Persamaan (26) untuk menghitung nilai akurasi.

$$
\text { Akurasi }=\frac{T P+T N}{T P+F N+F P+T N}
$$

Recall adalah proporsi dari kelas positif yang diklasifikasi dengan benar. Berikut Persamaan (27) akan menunjukkan perhitungan untuk nilai recall.

$$
\text { Recall }=\frac{T P}{T P+F N}
$$

Presisi adalah proporsi dari dari kelas positif yang diklasifikasikan benar positif dibandingkan dengan keseluruhan hasil yang diklasifikasikan positif. Persamaan (28) menunjukkan perhitungan untuk presisi.

$$
\text { Presisi }=\frac{T P}{T P+F P}
$$

\section{Hasil dan Pembahasan}

\subsection{Pengaruh Resolusi Citra Terhadap Akurasi}

Pengujian pertama dilakukan untuk menguji pengaruh resolusi citra terhadap akurasi. Pengujian ini bertujuan untuk mendapatkan resolusi citra yang lebih baik digunakan untuk mengklasifikasikan songket Lombok menggunakan fitur-fitur GLCM dan Moment Invariant. Citra dengan resolusi 64×64 piksel, 128x128 piksel, 256×256 piksel, dan 300×300 piksel digunakan pada proses pelatihan maupun proses pengujian, kemudian dilakukan perbandingan terhadap hasil klasifikasinya. Akurasi hasil klasifikasi berdasarkan resolusi citra dapat dilihat pada Tabel III.
TABEL III. PENGARUH RESOLUSI CITRA TERHADAP HASIL AKURASI

\begin{tabular}{|c|c|c|c|}
\hline \multirow{2}{*}{$\begin{array}{c}\text { Resolusi } \\
\text { Citra }\end{array}$} & \multicolumn{3}{|c|}{ Akurasi(\%) } \\
\cline { 2 - 4 } & $\mathrm{MI}$ & GLCM & MI+GLCM \\
\hline $64 \times 64$ & $20.33 \%$ & $41.67 \%$ & $42 \%$ \\
\hline $128 \times 128$ & $25.33 \%$ & $48.33 \%$ & $50 \%$ \\
\hline $256 \times 256$ & $35 \%$ & $71 \%$ & $70 \%$ \\
\hline $300 \times 300$ & $39.33 \%$ & $70 \%$ & $76 \%$ \\
\hline
\end{tabular}

Keterangan: $\mathrm{MI}=$ Moment Invariant

Dari Tabel III dapat dilihat bahwa hasil klasifikasi mengalami peningkatan seiring dengan meningkatnya resolusi citra yang digunakan. Peningkatan akurasi terjadi pada semua fitur yaitu Moment Invariant, GLCM, dan Moment Invariant+GLCM. Pada fitur Moment Invariant peningkatan akurasi dari citra 64×64 piksel ke citra $128 \times 128$ piksel yakni sebesar $5 \%$. Sedangkan peningkatan akurasi dari citra $128 \times 128$ piksel ke citra $256 \times 256$ piksel sebesar $9.67 \%$ saja. Dan untuk akurasi dari citra 256×256 piksel ke citra 300×300 piksel peningkatannya hanya sebesar $4.33 \%$. Peningkatan akurasi pada fitur Moment Invariant tidak terlalu signifikan yakni hanya sebesar $4.33 \%$ sampai 9.67\%. Pada fitur GLCM peningkatan akurasi dari citra 64x64 piksel ke citra $128 \times 128$ piksel tidak signifikan yakni sebesar $6.66 \%$ saja. Sedangkan peningkatan akurasi dari citra $128 \times 128$ piksel ke citra $256 \times 256$ piksel cukup signifikan yakni sebesar $22.67 \%$. Sedangkan pada saat citra diubah menjadi $300 \times 300$ piksel terjadi penurunan akurasi sebesar $1 \%$. Untuk fitur Moment Invariant+GLCM peningkatan akurasi dari citra 64×64 piksel ke citra $128 \times 128$ piksel sebesar $8 \%$. Sedangkan peningkatan akurasi dari citra $128 \times 128$ piksel ke citra $256 \times 256$ cukup signifikan yakni sebesar $20 \%$. Dan untuk akurasi dari citra 256×256 piksel ke citra 300×300 piksel peningkatannya sebesar $6 \%$ saja. Akurasi tertinggi diperoleh pada saat pengujian dengan fitur Moment Invariant+GLCM menggunakan resolusi citra $300 \times 300$ piksel yaitu sebesar $76 \%$.

Adapun akurasi untuk masing-masing kelas dapat dilihat dari nilai presisi dan recall. Tabel IV menunjukkan nilai presisi dan recall dari hasil klasifikasi berdasarkan resolusi citra. Nilai presisi dan recall pada Tabel IV juga mengalami peningkatan seiring dengan meningkatnya resolusi citra. Nilai presisi terkecil yaitu $21.14 \%$ dan nilai recall terkecil yaitu $21.17 \%$ diperoleh pada fitur Moment Invariant dengan resolusi citra 64x64 piksel. Sedangkan untuk nilai presisi terbesar yaitu $75.03 \%$ dan nilai recall terbesar yaitu $75.21 \%$ diperoleh pada fitur Moment Invariant+GLCM dengan 
resolusi citra $300 \times 300$ piksel. Hal ini menunjukkan bahwa resolusi citra berpengaruh terhadap akurasi. Semakin besar resolusi citra yang digunakan maka akurasi yang dihasilkan semakin baik.

TABEL IV. NILAI PRESISI DAN RECALL BERDASARKAN RESOLUSI CITRA

\begin{tabular}{|c|c|c|c|c|c|c|}
\hline \multirow{2}{*}{$\begin{array}{c}\text { Resol } \\
\text { usi } \\
\text { Citra }\end{array}$} & \multicolumn{2}{|c|}{$\mathrm{MI}$} & \multicolumn{2}{|c|}{$\mathrm{GLCM}$} & \multicolumn{2}{c|}{ MI+GLCM } \\
\cline { 2 - 7 } & $\mathrm{R}$ & $\mathrm{P}$ & $\mathrm{R}$ & $\mathrm{P}$ & $\mathrm{R}$ \\
\hline $64 \times 6$ & 21.1 & 21.1 & 40.2 & 39.4 & 42.3 & 40.7 \\
4 & $4 \%$ & $7 \%$ & $2 \%$ & $4 \%$ & $1 \%$ & $4 \%$ \\
\hline $128 \mathrm{x}$ & 23.9 & 24.9 & 47.0 & 47.0 & 49.1 & 48.5 \\
128 & $6 \%$ & $8 \%$ & $8 \%$ & $5 \%$ & $8 \%$ & $6 \%$ \\
\hline $256 \mathrm{x}$ & 34.5 & 34.8 & 70.6 & 70.2 & 70.0 & 69.1 \\
256 & $2 \%$ & $1 \%$ & $1 \%$ & $7 \%$ & $2 \%$ & $9 \%$ \\
\hline $300 \mathrm{x}$ & 40.6 & 39.1 & 70.6 & 68.7 & $\mathbf{7 5 . 0}$ & $\mathbf{7 5 . 2}$ \\
300 & $7 \%$ & $3 \%$ & $2 \%$ & $3 \%$ & $\mathbf{3 \%}$ & $\mathbf{1 \%}$ \\
\hline
\end{tabular}

Keterangan: $\mathrm{P}=\mathrm{Presisi}, \mathrm{R}=$ Recall, $\mathrm{MI}=$ Moment Invariant

Selain berpengaruh terhadap akurasi, resolusi citra juga mempengaruhi waktu komputasi. Citra dengan resolusi 64×64 piksel membutuhkan waktu komputasi yang singkat dibandingkan dengan citra 300×300 piksel. Tabel V menunjukkan waktu komputasi satu buah citra untuk masing-masing resolusi. Waktu komputasi diujj pada semua fitur.

TABEL V. PENGARUH RESOlUSI CITRA TERHADAP WAKTU KOMPUTASI DALAM SATUAN DETIK

\begin{tabular}{|c|c|c|c|}
\hline $\begin{array}{c}\text { Resolusi } \\
\text { Citra }\end{array}$ & MI & GLCM & MI+GLCM \\
\hline $64 \times 64$ & 0.0367 & 3.9534 & 4.0374 \\
\hline $128 \times 128$ & 0.1170 & 4.4586 & 4.7276 \\
\hline $256 \times 256$ & 0.4432 & 6.1799 & 6.7571 \\
\hline $300 \times 300$ & 0.6097 & 6.9797 & 7.7401 \\
\hline
\end{tabular}

Keterangan: $\mathrm{MI}=$ Moment Invariant

Berdasarkan Tabel V, dapat disimpulkan bahwa semakin besar resolusi yang digunakan, maka semakin lama waktu komputasi yang dibutuhkan. Semakin besar resolusi citra yang digunakan, maka semakin banyak piksel yang harus dihitung dan menyebabkan waktu komputasi meningkat.

Berdasarkan hasil pengujian pengaruh resolusi citra terhadap akurasi dapat diketahui bahwa peningkatan resolusi citra berpengaruh positif terhadap akurasi fitur, semakin besar resolusi citra, semakin bagus pula akurasinya. Akurasi terbaik diperoleh ketika pengujian dilakukan dengan menggunakan citra 300×300 piksel pada fitur Moment Invariant+GLCM dengan waktu komputasi yang cukup singkat yaitu 7.7401 detik untuk masing-masing citra.
Oleh karena itu, citra dengan resolusi $300 \times 300$ piksel merupakan resolusi citra terbaik dilihat dari akurasi dan waktu komputasi.

\subsection{Pengaruh Rotasi Terhadap Akurasi}

Pengujian selanjutnya dilakukan untuk mengetahui pengaruh rotasi terhadap akurasi klasifikasi. Pada pengujian ini, dataset yang digunakan yaitu citra dengan resolusi citra 300×300 piksel. Rotasi dilakukan searah jarum jam dengan rotasi 90 ㅇ dan 180․ Hasil dari pengujian pengaruh rotasi terhadap hasil klasifikasi dapat dilihat pada Tabel VI.

TABEL VI. PENGARUH ROTASI TERHADAP HASIL KLASIFIKASI

\begin{tabular}{|c|c|c|c|}
\hline \multirow{2}{*}{ Arah Rotasi } & \multicolumn{3}{|c|}{ Akurasi(\%) } \\
\cline { 2 - 4 } & $\mathrm{MI}$ & $\mathrm{GLCM}$ & $\mathrm{Ml}+\mathrm{GLCM}$ \\
\hline 0 & $39.33 \%$ & $70 \%$ & $76 \%$ \\
\hline $90 \circ \mathrm{CW}$ & $38.66 \%$ & $74.33 \%$ & $68.66 \%$ \\
\hline $180 \circ \mathrm{CW}$ & $37.33 \%$ & $71 \%$ & $66.33 \%$ \\
\hline
\end{tabular}

Dari Tabel VI dapat disimpulkan bahwa rotasi 90 ․ CW dan 180 ․ CW tidak berpengaruh besar terhadap akurasi. Akurasi dari fitur Moment Invariant mengalami perbedaan baik pada rotasi $90 \circ \mathrm{CW}$ maupun 180 ㄷW. Hal ini disebabkan karena perbedaan hasil ekstraksi fitur pada beberapa citra saat dirotasi. Perbedaan akurasi hanya sebesar $0.67 \%$ untuk rotasi $90 \circ \mathrm{CW}$ dan sebesar $2 \%$ untuk rotasi $180^{\circ} \mathrm{CW}$. Untuk fitur GLCM akurasi mengalami sedikit peningkatan pada saat dirotasi. Peningkatan akurasinya sebesar $4.33 \%$ untuk rotasi 90 ㅇ dan sebesar $1 \%$ untuk rotasi $180^{\circ} \mathrm{CW}$. Hal ini disebabkan karena pada GLCM pembentukan matriks GLCM dilakukan dengan menggunakan empat sudut, yaitu 0 o

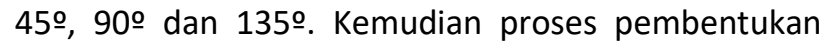
matriks GLCM juga dilakukan dengan memeriksa setiap 2 matriks berdekatan secara dua arah (simetris) sehingga pada citra rotasi 90 o dan 180 o tidak terjadi banyak perubahan akurasi. Sedangkan untuk fitur Moment Invariant+GLCM mengalami sedikit penurunan akurasi pada saat dirotasi. Penurunan akurasinya sebesar $7.34 \%$ untuk rotasi 90 ㅇ dan sebesar $9.67 \%$ untuk rotasi 180 ․W.

Adapun untuk presisi dan recall memiliki nilai yang tidak jauh berbeda dengan akurasi. Tabel VII menunjukkan nilai presisi dan recall untuk hasil klasifikasi citra berdasarkan rotasi. Nilai presisi dan recall pada Tabel VII berdasarkan rotasi citra pada fitur Moment Invariant, GLCM, dan Moment Invariant+GLCM secara umum tidak berbeda jauh. Hal ini menunjukkan bahwa songket Lombok dapat dikenali menggunakan fitur-fitur tersebut. 
TABEL VII. NILAI PRESISI DAN RECALL BERDASARKAN ROTASI CITRA

\begin{tabular}{|c|c|c|c|c|c|c|}
\hline \multirow{2}{*}{$\begin{array}{c}\text { Arah } \\
\text { Rotas } \\
\mathrm{i}\end{array}$} & \multicolumn{2}{|c|}{$\mathrm{MI}$} & \multicolumn{2}{c|}{ GLCM } & \multicolumn{2}{c|}{ MI+GLCM } \\
\cline { 2 - 7 } & $\mathrm{P}$ & $\mathrm{R}$ & $\mathrm{P}$ & $\mathrm{R}$ & $\mathrm{P}$ & $\mathrm{R}$ \\
\hline 0ㅇ & 40.6 & 39.1 & 70.6 & 68.7 & 75.0 & 75.2 \\
& $7 \%$ & $3 \%$ & $2 \%$ & $3 \%$ & $3 \%$ & $1 \%$ \\
\hline 90 ㅇ & 40.3 & 38.5 & 74.9 & 73.5 & 68.8 & 68.6 \\
$\mathrm{~W}$ & $2 \%$ & $4 \%$ & $9 \%$ & $1 \%$ & $4 \%$ & $6 \%$ \\
\hline 180 을 & 37.9 & 36.9 & 71.7 & 70.1 & 66.5 & 65.4 \\
$\mathrm{CW}$ & $9 \%$ & $3 \%$ & $7 \%$ & $1 \%$ & $5 \%$ & $3 \%$ \\
\hline
\end{tabular}

Keterangan $\mathrm{P}=\mathrm{Presisi}, \mathrm{R}=$ Recall, $\mathrm{MI}=$ Moment Invariant

Berdasarkan hasil pengujian pengaruh rotasi terhadap akurasi, dapat disimpulkan bahwa rotasi dengan arah 90ㄷW dan 180CW tidak berpengaruh besar terhadap nilai akurasi, presisi, dan recall. Pada rotasi dengan arah $90 \circ \mathrm{CW}$ dan $180^{\circ} \mathrm{CW}$ citra masih dapat dikenali.

\subsection{Fitur-fitur GLCM dan Moment Invariant yang Paling Efektif}

Pengujian selanjutnya yaitu memeriksa fitur-fitur yang paling efektif pada GLCM dan Moment Invariant. Pengujian ini bertujuan untuk mengetahui fitur-fitur yang paling efektif digunakan pada klasifikasi songket Lombok. Pada pengujian ini, dataset yang digunakan yaitu citra dengan resolusi citra 300×300 piksel. Pengujian ini dimulai dengan menggunakan seluruh fitur pada setiap metode. Setelah itu, jumlah fitur masukan dikurangi satu persatu pada setiap langkah. Fitur yang memberikan hasil terbaik pada setiap langkah digunakan untuk langkah berikutnya. Hasil dari pengujian ini dapat dilihat pada Tabel VIII dan Tabel IX.

TABEL VIII. SELEKSI FITUR MOMENT INVARIANT

\begin{tabular}{|c|c|c|}
\hline Jumlah Fitur & Fitur Yang dibuang & Akurasi \\
\hline 7 & - & $39.33 \%$ \\
\hline 6 & Moment Ke-5 & $42 \%$ \\
\hline 5 & Moment Ke-1 & $42 \%$ \\
\hline 4 & Moment Ke-4 & $37.66 \%$ \\
\hline 3 & Moment Ke-2 & $27.33 \%$ \\
\hline 2 & Moment Ke-6 & $21.33 \%$ \\
\hline 1 & Moment Ke-3 & $10.66 \%$ \\
\hline
\end{tabular}

Dari Tabel VIII dapat dilihat bahwa akurasi dari Moment Invariant mengalami peningkatan pada saat nilai Moment ke 5 dan Moment ke 1 dibuang yaitu sebesar $42 \%$. Ini menunjukkan bahwa nilai Moment ke 2,3,4,6 dan 7 adalah fitur Moment Invariant yang paling efektif digunakan pada klasifikasi songket Lombok.
TABEL IX. SELEKSI FITUR GLCM

\begin{tabular}{|c|c|c|}
\hline Jumlah Fitur & Fitur Yang dibuang & Akurasi \\
\hline 5 & - & $70 \%$ \\
\hline 4 & Contrast & $98.33 \%$ \\
\hline 3 & Correlation & $98.33 \%$ \\
\hline 2 & Energy & $92.66 \%$ \\
\hline 1 & IDM & $91.66 \%$ \\
\hline
\end{tabular}

Dari Tabel IX dapat dilihat bahwa akurasi dari GLCM mengalami peningkatan dengan dikuranginya jumlah fitur masukan. Akurasi tertinggi diperoleh pada saat fitur Contrast dan Correlation dibuang yaitu sebesar $98.33 \%$. Ini menunjukkan bahwa fitur Energy, IDM dan Entropy adalah fitur yang paling efektif digunakan pada klasifikasi songket Lombok.

Berdasarkan hasil pengujian dari memeriksa fiturfitur yang paling efektif, dapat disimpulkan bahwa fitur-fitur Moment Invariant yang paling efektif digunakan pada klasifikasi songket Lombok adalah nilai Moment ke 2, 3, 4, 6, dan 7. Sedangkan untuk fitur-fitur GLCM yang paling efektif digunakan pada klasifikasi songket Lombok adalah fitur Energy, IDM, dan Entropy.

\subsection{Klasifikasi Menggunakan Fitur yang Paling Efektif}

Pengujian selanjutnya menggunakan fitur Moment Invariant+GLCM yang paling efektif. Pada pengujian ini, resolusi citra yang digunakan adalah 300×300 piksel. Pengujian ini bertujuan untuk mengetahui apakah dengan fitur yang paling efektif bisa menghasilkan akurasi yang lebih tinggi dari pengujian sebelum menggunakan fitur yang paling efektif. Hasil dari pengujian ini dapat dilihat pada Tabel $X$.

TABEL X. HASIL KLASIFIKASI FITUR MOMENT INVARIANT+ GLCM YANG PALING EFEKTIF

\begin{tabular}{|l|l|l|}
\hline Akurasi & Presisi & Recall \\
\hline $96.67 \%$ & $96.47 \%$ & $96.36 \%$ \\
\hline
\end{tabular}

Dari Tabel $\mathrm{X}$ dapat dilihat bahwa penggabungan fitur Moment Invariant+GLCM yang paling efektif memberikan dampak yang baik pada hasil akurasi. Akurasi yang didapat pada pengujian ini sebesar 96.67\%. Hasil akurasi pada pengujian ini mengalami peningkatan sebesar $20.67 \%$ dari pengujian sebelum menggunakan fitur yang paling efektif yakni sebesar 76\%. Sedangkan untuk nilai presisi dan recall didapatkan hasil sebesar $96.47 \%$ untuk presisi dan 96.36\% untuk recall. Nilai presisi dan recall juga mengalami peningkatan sebesar $21.44 \%$ untuk presisi dan $21.15 \%$ untuk recall dari pengujian sebelum 
menggunakan fitur yang paling efektif yakni sebesar 75.03\% untuk nilai presisi dan $75.21 \%$ untuk nilai recall.

Berdasarkan hasil dari pengujian menggunakan fitur yang paling efektif, dapat disimpulkan bahwa dengan menggunakan fitur yang paling efektif memberikan peningkatan hasil pada akurasi, presisi, dan recall.

\section{KeSIMPULAN DAN SARAN}

\subsection{Kesimpulan}

Berdasarkan penelitian yang telah dilakukan, dapat disimpulkan bahwa:

a. Resolusi citra $300 \times 300$ piksel adalah resolusi citra terbaik jika dilihat dari nilai akurasi, presisi dan recall.

b. Perubahan resolusi citra memberikan pengaruh pada akurasi yang didapat dan memberikan peningkatan pada waktu komputasi.

c. Rotasi sebesar 90 으 dan 180 ㅇaㄱ searah dengan jarum jam tidak berpengaruh besar terhadap hasil akurasi. Citra yang telah dirotasi masih dapat dikenali oleh sistem.

d. Fitur yang paling efektif untuk klasifikasi songket Lombok adalah fitur Moment Invariant yang ke 2, 3, 4, 6, dan 7. Sedangkan untuk GLCM fitur yang paling efektif adalah fitur IDM, Entropy dan Energy.

e. Akurasi tertinggi diperoleh pada fitur GLCM dengan resolusi citra $300 \times 300$ piksel menggunakan fitur yang paling efektif yakni sebesar $98.33 \%$.

f. Dengan menggunakan fitur yang paling efektif mampu meningkatkan akurasi dari $76 \%$ menjadi $96.67 \%$ pada fitur Moment Invariant+GLCM.

g. Metode GLCM untuk ekstraksi fitur tekstur cocok digunakan pada klasifikasi songket Lombok dengan akurasi $98.33 \%$.

\subsection{Saran}

Adapun saran untuk penelitian selanjutnya yaitu:

a. Lakukan klasifikasi songket Lombok dengan menggunakan ciri atau fitur yang lebih banyak.

b. Tambahkan parameter uji untuk mengklasifikasi songket Lombok.

c. Perbanyak warna songket pada setiap motif.

d. Lakukan cropping dan resizing di sistem.

\section{UCAPAN TERIMA KASIH}

Ucapan terima kasih diberikan kepada pak Satriadi pemilik art shop songket yang telah menyediakan songket untuk pengumpulan data.

\section{DAFTAR PUSTAKA}

[1] I. Salamah and R. Kusumanto, "Faktor-Faktor Pemanfaatan Teknologi Informasi UKM Kain Tenun Songket Palembang," J. RESTI (Rekayasa Sist. dan Teknol. Informasi), vol. 1, no. 3, pp. 177-182, 2017.

[2] I. P. G. S. Andisana, M. Sudarma, and I. M. O. Widyantara, "Pengenalan Dan Klasifikasi Citra Tekstil Tradisional Berbasis Web Menggunakan Deteksi Tepi Canny, Local Color Histogram Dan CoOccurrence Matrix," Maj. IIm. Teknol. Elektro, vol. 17, no. 3, pp. 401-408, 2018.

[3] N. A. H, W. Hapsari, A. Angesti, and S. Felixiana, "Penggunaan Momen Invariant, Eccentricity, Dan Compactness Untuk Klasifikasi Motif Batik Dengan KNearest Neighbour," Informatika, vol. 11, no. 2, pp. 107-115, 2015.

[4] R. Fauzana, D. I. B. Hidayat, and P. D. H. Suhardjo, "Image Processing Of Periapical Radiograph On Abscess Disease Detection Using Linear Discriminant Analysis Method Based On Android," e-Proceeding Eng., vol. 4, no. 1, pp. 106-114, 2017.

[5] Gressiva and F. Candra, "Sistem Pengenalan Motif Songket Melayu Menggunakan Ekstraksi Fitur Principal Component Analysis dan Gray Level CoOccurence Matrix dan Jaringan Saraf Tiruan," Univeristas Riau, vol. 5, no. 2, pp. 1-7, 2018.

[6] R. Mufailah and Aripin, "Ekstraksi Fitur Menggunakan GLCM (Gray Level Co- Occurrance Matrix) Dan Jarak Euclidean Untuk Pengenalan Jenis Batik Tulis Dan Batik Cap," Univ. Dian Nuswantoro, 2013.

[7] Nuraedah and M. Bakri, "Klasifikasi Motif Kain Tradisional Batik Bomba Kaili," Semin. Nas. Sist. Inf. UNMER Malang, no. 14, pp. 715-723, 2017.

[8] R. Yulianti, I. G. P. S. Wijaya, and F. Bimantoro, “Pengenalan Pola Tulisan Tangan Suku Kata Aksara Sasak Menggunakan Metode Moment Invariant dan Support Vector Machine," J-COSINE, vol. 3, no. 2, pp. 91-98, 2018.

[9] M. R. Raharjo, "Analisa Klasifikasi Jenis Pohon Mangga Berdasarkan Tekstur Daun," Technologia, vol. 7, no. 3, pp. 155-162, 2016.

[10] I. W. H. Narandika, B. Hidayat, and J. Arif, "Identifikasi Ras Manusia Melalui Citra Wajah Menggunakan Metode Histogram of Oriented Gradient dan Klasifikasi Linear Discriminant Analysis," Semin. Nas. Inov. dan Apl. Teknol. di Ind. 2019, pp. 182-187, 2019.

[11] E. Budiman, E. Santoso, and T. Afirianto, "Pendeteksi 
Jenis Autis pada Anak Usia Dini Menggunakan Metode Linear Discriminant Analysis (LDA)," J. Pengemb. Teknol. Inf. dan Ilmu Komput., vol. 1, no. 7, pp. 583-592, 2017.

[12] Fandiansyah, J. Y. Sari, and I. P. Ningrum, "Pengenalan Wajah Menggunakan Metode Linear Discriminant Analysis dan k Nearest Neighbor," J. Ultim., vol. 9, no. 1, pp. 1-9, 2018.

[13] R. Farinda, Z. R. Firmansyah, C. Sulton, I. G. P. S. Wijaya, and F. Bimantoro, "Beef Quality Classification based on Texture and Color Features using SVM Classifier," J. Telemat. Informatics, vol. 6, no. 3, 2018.

[14] H. Wijayanto, "Klasifikasi Batik Menggunakan
Metode K-Nearest Neighbour Berdasarkan Gray Level Co-Occurrence Matrices (GLCM)," Univ. Dian Nuswantoro, 2015.

[15] F. U. Karimah, Ernawati, and D. Andreswari, "Rancang Bangun Aplikasi Pencarian Citra Batik Besurek Berbasis Tekstur Dengan Metode Gray Level Co- Occurrence Matrix Dan Euclidean Distance," J. Teknol. Inf., vol. 11, no. 1, pp. 64-77, 2015.

[16] E. P. Satrio and T. Sutojo, "Klasifikasi Tenun Menggunakan Metode K-Nearest Neighbour Berdasarkan Gray Level Co-Occurrence Matrices (GLCM)," Univ. Dian Nuswantoro, 2016. 